\title{
Sobre trote e violência
}

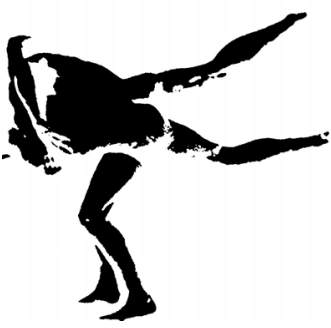

Sueli Terezinha Ferreira Martins 1

O artigo "Tradição, trote e violência" traz para nossa reflexão vários aspectos importantes. Segundo pesquisa citada, a violência entre os jovens de todas as classes sociais tem aumentado nos últimos anos. A banalização da violência nas várias esferas das relações sociais parece subsidiar sua "naturalização", formando representações que legitimam muitos comportamentos violentos. O individualismo, a competição, o consumismo e o enfraquecimento de uma ética que respeite o outro, caracterizam de forma hegemônica o estar no mundo hoje. A possibilidade do desenvolvimento do indivíduo e cidadão parece ser cada vez mais uma utopia. Conseqüência da alienação presente nas relações sociais, o indivíduo perde progressivamente o controle sobre sua vida. Neste sentido, a questão da violência precisa ser tratada como um fenômeno social, que extrapola os muros das faculdades. Ela está presente em todos os espaços na sociedade atual. Na verdade, o trote nas Faculdades de Medicina é uma tradição construída no decorrer de muitos séculos e que se mantém até os dias atuais. É, portanto, uma prática violenta há muito tempo. Cabe perguntar se o contexto atual, com o aumento da violência em todas as camadas $e$ espaços sociais, contribui ou não para a exacerbação da violência no ritual de recepção dos novos alunos na faculdade. Em que medida a "naturalização" da violência está presente na população privilegiada que "consegue" uma vaga na universidade, em um curso tão concorrido como o de Medicina? A fala do estudante Luiz Felipe Lisboa indica, de certo modo, esse processo

${ }^{1}$ Psicóloga social, professora do Departamento de Psicologia e do Programa de Pós-Graduação em Educação para a Ciência, Faculdade de Ciências de Bauru, Unesp. 
quando diz que o "limiar de violência" dos alunos há muito tempo está aumentando. Desrespeitar, invadir o espaço do outro, humilhar, segundo suas palavras, não são considerados atos violentos. A história recente nos diz que este caminho é um grande equívoco, perigoso, o início da justificação para a violência física e para a exclusão. Basta olharmos para a história dos índios, dos negros, dos judeus, de militantes políticos de esquerda e tantos outros grupos que sofreram violências ímpares. Foram desrespeitados em seus direitos, humilhados publicamente no seu dia-a-dia, desqualificados e excluídos. O que ocorre no trote não é diferente: é violência, coerção, o exercício do poder de uns sobre outros: forma medieval de recepcionar os colegas, de deixar claro, desde o início, quem ali detém o poder.

Considerando a violência um fenômeno social e o trote como uma das formas de expressá-la, parece relevante que quase $25 \%$ dos calouros da USP tenham escolhido não participar do trote. Quem são esses quarenta alunos $e$ o que pensam sobre o trote? Por que optaram pela não participação? Conheciam as conseqüências deste ato? Talvez esteja aí um pólo importante para a discussão necessária sobre essa prática. Mesmo sob forte pressão dos veteranos, que pode se manter no decorrer dos seis anos de faculdade, aquelas pessoas mantiveram seu direito de escolher e de enfrentar as conseqüencias de seus atos. Provavelmente este dado se repita em outras faculdades.

Os autores colocam como uma das possibilidades de explicar o comportamento violento nos rituais de recepção o fato de o curso médico ser física e mentalmente desgastante. Será que o trote não faz parte de um conjunto de ações que fortalecem a corporação médica? Ou a primeira prova, de muitas outras que virão, para que o recém-chegado passe a ocupar um espaço privilegiado? Não será o sofrimento anterior à entrada na faculdade, assim como os outros sofrimentos que o curso impõe a seus alunos, uma forma de tentar garantir o status do profissional médico, mesmo em um contexto perverso como o atual, que não garante mais condições de trabalho decentes para esse e outros profissionais?

Gostaria de ressaltar o reflexo dessa prática nas relações sociais em geral, e na prática médica em particular. Aspectos como autoritarismo, relação de poder, individualismo etc., se reproduzem na prática médica, sendo apontados, inclusive por pesquisas, principalmente na saúde pública, como um problema relevante da relação médico-paciente, que se caracteriza de modo semelhante à relação que o aluno encontra na faculdade. Esse modelo, muitas vezes, se reproduz na relação médico-equipe de saúde (profissionais de outras áreas, auxiliares etc.), mantendo-se, portanto, uma relação de poder permeada pela violência sutil.

Sem dúvida, trote e violência andam tradicionalmente juntos. Concordo que a saída é promover uma ampla e corajosa discussão a respeito das atitudes vigentes, tendo como ponto de partida o trote, enquanto uma das práticas violentas, mas reconhecendo que ela não é a única. Questionar a formação, em seus vários aspectos, parece-me questão urgente, já que suas conseqüências não se restringem ao âmbito do curso, mas interferem na futura prática do profissional e na relação deste com a equipe de trabalho $e$ a população atendida. 